\title{
UNIVERSITY, CHURCH, AND SOCIAL CHANGE: THE CASE OF CATHOLIC COLLEGES IN ONTARIO, 1931-1961
}

\author{
Brian F. Hogan
}

\section{Section 1: Introduction}

This paper is based upon research covering the period 1931-61 and is aimed at examining relationships between Roman Catholic social teaching and consequent social action within the Province of Ontario. The seven studies constituting the research focused on six distinct areas in and around the cities of Windsor, London, Hamilton, Toronto, Ottawa, and Sudbury. Excluding seminaries or theologates, four of these cities contained one Catholic post-secondary institution, typically identified as an 'Arts and Science' college or university, and the city of Ottawa contained two such institutions.

The original research was concerned with identifying the range of personal and institutional efforts contributing to the development of social action initiatives, without particular regard to educational affiliation. Finally, however, such identification proved to be a key consideration in the analysis of the relationship between reflection and praxis. This essay focuses on that identification in an attempt to gain a clearer understanding of the relationship among religious commitment, educational activity, and initiatives for social action occurring within the province during this thirty-year period. The paper proceeds by way of a brief introduction to a number of Max Weber's interpretive categories. It then establishes the context of the research, and offers a summary account of the research findings for two of the areas. It concludes with a reflection on the findings within a Weberian interpretive framework.

\section{Section 2: Weberian Interpretive Themes}

As one means of accessing and deciphering the data which has been accumulated, the essay employs a number of categories developed or employed by Max Weber in his studies of the relationship between religious belief and the ways in which such belief has found expression within the structures and values of a given society. Two cautionary notes are advisable. The first is that the terms, 
categories, dichotomies, ideal-types, and typologies employed by Weber are not normally clear and distinct. In fact they are frequently at least ambiguous, and at times contradictory. They do, nonetheless, provide a rich array of investigative tools for such analysis, so long as one remembers that ideal-types and typological categories are just that, ty pes and categories, and are not identical with the realities they seek to limn. A A second advisory relates to the fact that these categories were developed for application at the macroscopic level of societies, civilizations, and whole systems of belief. The present effort at employing these aids at a microscopic level so restricted in time, space, and intent, attempts to keep this limitation clearly in mind.

Among the categories and ideal-types employed by Weber which are helpful for this investigation are the following. First, is religion essentially a static or a dynamic phenomenon? Does religious belief concentrate its emphasis on preservation and conservation of the status quo, or is it focused on responding to the needs of a given time and place? In the first case, of course, religion becomes something of a self-serving phenomenon which must very quickly assume a crustacean facade. In the second, religion must employ at least some of the intellectual, critical tools available to it, in order to investigate and to respond to contemporary needs with appropriate deeds, or at least dicta. In this latter case the educational apparatuses of the time and place become crucial to the operative life of the religion and its adherents, as an effort is made to adjust to changing

1. A good recent essay on this topic is 'Max Weber and Social Change,' in Roger O'Toole, Religion: Classic Sociological Approaches (Toronto: McGraw Hill Ryerson Ltd., 1984), 111-84. The classic presentation of Weber's work on religion in English can be found in Max Weber, The Sociology of Religion, trans. Ephraim Fischoff (Boston: Beacon Press, 1964). This translation contains an extended introduction by Talcott Parsons, one of the first systematic, if controverted, interpreters of Weber for the Anglo world. The text edited by H.H. Gerth and C. Wright Mills, From Max Weber: Essays in Sociology (New York: Oxford University Press, 1946), 267-362, provides ease of access to a number of Weber's writings on religion in Part III. A good introduction to the man, his writings, influence, and ancillary literature can be found in a number of articles located in the International Encyclopedia of the Social Sciences (New York: MacMillan, 1968). See especially: Reinhard Bendix, 'Weber, Max'; Robert N. Bellah, 'Religion: The Sociology of Religion'; Victor W. Turner, 'Religious Specialists: Anthropological Study.' Chapter 8 of Reinhard Bendix, Max Weber: An Intellectual Portrait (Garden City: Doubleday, 1962), 257-81, locates Weber's religious studies within the whole context of his life's labours. The typologies which have served so well as structural agents for systematic inquiry into relations between religious belief and social expression are simultaneously highly elusive, in part perhaps because this area of Weber's work was never brought to systematic, mature expression. The very ambiguity and elasticity of the concepts provides for a rich selection for interpretation and application but contributes not a little to the interpretive controversies associated with Weberian studies and explication. 
cultural conditions. For Talcott Parsons it is clear that 'Weber's primary interest is in religion as a source of the dynamics of social change, not religion as a reinforcement of the stability of societies. ${ }^{2}$

Second, what relations are seen to inhere, in these studies, between the categories 'expressive' and 'behaviour,' where expressive refers to the belief structure, its content and intent, and behaviour refers to the actions which are consequent on such belief? ${ }^{3}$ Here again the range of educational institutions, with their belief structures, emphases, and activities, is seen as crucial for examining and understanding relations between intentions and actions. ${ }^{4}$

Third, Weber's exploration of the functions fulfilled by, and the relations implicit among, magician, priest, and prophet, provides yet another avenue of analysis. These particular categories provide a very helpful optic for viewing the strains and stresses within religious and cultural institutions undergoing change.

Finally, Weber himself took a very dim view of the prospects for modern, rational cultures, seeing no help but for an inevitable entombment within the uncompromising 'iron cage of reason.' In the end bureaucracy (and the modern person) would be ensnared and befuddled by the very webs of reason (even reasonable webs) which initially so advanced human efforts and served human needs. What, if anything, do these studies have to say about such inevitable limitations and entrapments, as perceived within this range of Ontario educational, ecclesial, and civil institutions during decades of very rapid social adjustment?

2. Talcott Parsons, 'Introduction,' in Weber, The Sociology of Religion, 30.

3. The terms 'expressive' and 'behaviour' are not Weber's, but they are among the chief categories by way of which American sociologists have attempted to interpret and to communicate the intent and effect of Weber's thought on society.

4. During the twentieth century the range of Catholic social action initiatives gathered under the umbrella term 'Catholic Action,' operative until the 1970s, took as their guiding directive the watchwords 'See, Judge, and Act.' A human activity was understood to be integral and complete when all three levels were perceived to be operative: a situation was critically examined, a decisive judgement was rendered on the basis of the evidence and the belief structure of the examiner, and concrete activity followed from that judgement to ensure that the perception obtained in the first two levels of reflection ushered in a new conception in the order of concrete circumstances. To employ a term conjured by Edward de Bono in Six Action Shoes (New York: Harper-Collins, 1991), the move from reflection to 'operacy' was absolutely essential for the integrity of human activity. The categories 'See, Judge, and Act' metamorphosed with Liberation Theology into the dynamic dialectic understood to inhere between praxis-reflection-praxis, the emphasis now changed from reflection in the first instance to praxis as providing the initiating moment. 


\section{Section 3: Geographical, Social, and Ecclesial Context}

Between 1931 and 1961, when the Canadian population increased from $10,376,786$ to $18,238,247$, the population of the province of Ontario advanced from 3,431,683 to 6,236,092. During these same years, the Catholic population of Ontario more than doubled, from 745,782 to $1,873,110$. These figures represented an aggregate percentage increase from 21.7 percent of the Ontario population in 1931 to 30 percent of the population in 1961. While Catholics were not in the majority, the numbers indicate the importance of studying this body as a contribution to appreciating the social complexity of the province.

To understand the position and practice of the Roman Catholic Church in Ontario, a negative description is probably the most helpful. That is to say, the Church in Ontario is neither British nor continental, nor is it the Church of the United States or of Quebec. In great part it has been influenced by the traditions and experiences of Catholics from all of these jurisdictions, but while sections of the province might best be described as falling within the penumbra of one or more of these influences, no one can be said to dominate.

Within the Province of Ontario a system of Catholic public elementary schools has obtained since the decades prior to Confederation in 1867. That constitutional arrangement sanctioned and continued the practice. With the development of high school education as increasingly the norm, a Catholic high school system emerged from earlier foundations, not without financial difficulties. Similarly, a tertiary level of education services developed, including colleges, universities, seminaries, and theologates, both English, French, and bilingual. This research has focused on the universities and colleges of the province, with particular attention directed towards Assumption College/University in Windsor, the University of St. Michael's College in Toronto, the University of Sudbury/Université de Sudbury in Sudbury, and the University of Ottawa/Université d'Ottawa and St. Patrick's College, both in the Canadian capital. Each of these institutions, except for the University of Ottawa, enjoyed a relationship, frequently of federation or association, with a larger public university.

Catholic colleges and universities offered a particularly favourable base for promoting social Catholicism. Here professors with a philosophical and theological appreciation for the significance of social teachings could explore the application of such teachings in the context of their professional work as economists, historians, social scientists, or ethicists. In fact, it is here that we find some of the most interesting manifestations of Ontario social Catholicism as the ivory tower encountered the grass roots. During the 1940s and 1950s, the Centre social/Social Centre of the University of Ottawa supported study groups, produced correspondence courses, and advanced a whole range of efforts intended to communicate the message of Catholic social teaching. In Windsor, the more informal Pius XI Labour School at Assumption University offered courses and provided a forum for Windsor labour leaders to reflect on social questions in general and those affecting labour matters in particular. During the 1950s and 
early 1960s, faculty and students associated with the Institute of Social Action located at St. Patrick's College in Ottawa were responsible for initiatives in the area of labour unions and co-operative and credit union endeavours. The inauguration of an extension course for miners at the University of Sudbury in 1958 provided an opportunity for advancing workers' education in that northern Ontario centre. At St. Michael's College in Toronto, at the Jesuit Regis theology school, and at St. Jerome's College in Kitchener, interest in a variety of social questions manifested itself in the development and support of courses either in the regular curriculum or in Extension Departments, and in the advocacy of study groups and public lecture series.

Apart from support for union activities, perhaps the most significant expression of social Catholicism in Canada is represented in the consistent support of co-operatives, caisses populaires, and credit unions. Practical support for this development, as for other social Catholic endeavours, was supplied by the Antigonish movement, founded at St. Francis Xavier University in Nova Scotia. ${ }^{5}$ Dozens of co-operative efforts and hundreds of credit unions resulted during the 1930s, 1940s, and 1950s. In the vast majority of these cases local clergy precipitated interest, or at the very least served as legitimating agents for the development of new and rather daring economic institutions for their people.

The general import of 'Catholic Action' organizations in twentieth-century Catholicism was to draw attention to the fact that religious expression and life experiences were to be viewed as integral. Education was a key concern of Catholic Action. The watchwords of the Young Christian Workers, 'See, Judge, and Act,' were followed in one form or another by all Catholic Action groups. This required a careful study of the local milieu and reflection on local conditions as preliminary to the process of initiating improvement. At its best, reflection and discussion were rooted in the concrete realities of family, work, and community interests. Accordingly, there was a natural progression from initial concern over working circumstances to a concern for strengthening and stabilizing marriage and family relationships. Catholic Action benefited from the fact that Canadians were placing greater emphasis on the importance of education through these decades. Catholic Action encouraged this development and stimulated greater interest in pursuing knowledge as a way of both understanding and modifying life situations.

5. The 'Antigonish Movement' was developed by Drs. Moses Coady and Jimmy Tompkins, clerics of the diocese of Antigonish, in response to the economic difficulties of the peoples of Atlantic Canada during the 1920s. The Movement placed a heavy emphasis on education. It worked to develop skills and institutions to support co-operative endeavours by which people who were usually economically marginalized could take some greater control of their economic environment. In the late 1950 s the Movement assumed a greater international character with the development of the Coady Institute, designed to assist persons from other countries to master such skills for adapted application to their own socio-political milieux. 
Among Canadian church concerns of importance for this consideration, educational experiences and initiatives are primary. Many Canadian clerics benefited from opportunities to study philosophy, theology, and the social sciences in European centres. The requirements for professional preparation for the faculties of Ontario's Catholic post-secondary schools insured a familiarity with current thought and teaching in the British and continental universities. As well, it would be difficult to over-estimate the impact of the presence and teaching of such luminaries as Jacques Maritain and Etienne Gilson, the most distinguished among a number of formative Catholic thinkers attracted to Toronto under the aegis of St. Michael's Pontifical Institute of Mediaeval Studies. Maritain's True Humanism and Man and the State presented a social philosophy which influenced a generation of Canadian Catholic students and faculty. His emphasis on the right relationship between individuals and the state, and his insistence on Christian social responsibility, accompanied a spirited defence of democratic rights and a consistent emphasis on the centrality of personal freedom. His presentation of these social and philosophical principles represented the finest flowering of Pope Leo XIII's dream of the possibilities of a careful reconsideration of the philosophical thought of Thomas Aquinas for the modern age.

Catholic colleges and universities served as key agencies for promoting and publicizing items of a social nature. A number of faculty and students at all universities were involved with courses, lectures, seminars, and debates running the range of social interest questions. They distributed Dorothy Day's Catholic Worker, as well as the Social Forum, at factory gates, and participated in volunteer work for Catherine de Hueck's Friendship Houses and other social service agencies. They were members of Young Christian Student (YCS) groups and later of Young Christian Worker (YCW) organizations. They sought to apply emerging Christian social philosophy to their time and place, and benefited from the writings of Jacques Maritain and the personalist and solidarist philosophies espoused by Catholic social leaders, both lay and clerical. For faculty, social Catholicism offered an opportunity for bringing professional knowledge and disciplines to bear on practical problems.

Given this geographical, social, and ecclesial context, a sampling of Catholic activities within two institutions will provide the basis for a Weberian reading of the significance of these experiences.

\section{Section 4: The University of St. Michael's College}

When the Priests of St. Basil (Basilian Fathers) decided to come to Toronto from France in the mid-nineteenth century, they were motivated by two concerns. The first was to provide pastoral assistance to the mass of new immigrants, mainly Irish and desperately poor, who had emigrated in recent years. Through education they intended to provide for an indigenous clergy to serve the new diocese. The second was, again through education, to insure that these new, impoverished, 
Canadians would have access to full participation in their society. At the time there were no Catholic secondary or college schools and many of the Canadian Irish resisted sending their children to state schools for fear that their faith might be compromised. Because of this lack of education, as one Basilian observed shortly after the arrival of the new clergy in Toronto,

these young men remain in a state of inferiority which humiliates them and which is no less prejudicial to religion than to themselves. One almost looks upon these poor [Canadian] Irish Catholics as a class incapable of fulfilling lofty employment, only good for mechanical tasks, to dig canals, level roads, work in mines, etc., under the direction of an intelligent man. If orthodoxy was not so deeply rooted in their hearts, we should count their apostasies by the thousands. ${ }^{6}$

A former student of the Basilians in France, the new Bishop of Toronto, François de Charbonnel, immediately realised that a Catholic college was needed to 'raise the intellectual level of the young men and permit them to advance to a higher echelon of society. ${ }^{, 7}$ It was clear to these priests, from the beginning of their ministry in Upper Canada, that civil and ecclesial concerns were inextricably united around the need for proper education. During the next generations the development of a high school, college, university, the Pontifical Institute of Mediaeval Studies, and a theological faculty at St. Michael's, signified the dual concern of the founders to assist a people in continuing their religious tradition while entering into full participation in their socio-economic-political milieu.

Eighty years after their arrival in Toronto the priests found themselves, like others around the world, in the midst of a terrible and extended depression. The campus response to the depression conditions, and a series of efforts into the 1950 s, suggest imaginative attempts to alleviate daunting problems. In the face of the depression Pope Pius XI issued a papal encyclical, Quadragesimo anno, in 1931, on the fortieth anniversary of Pope Leo's statement concerning the new conditions of industrial and urban life, Rerum novarum.

During the summer of 1931, the Rev. Henry Carr, CSB, who served simultaneously as superior of the Congregation of St. Basil and as the first President of St. Michael's Institute of Mediaeval Studies, wrote a series of pamphlets entitled Letters to Mildred: Chats on Christian Economics. The booklets, between twenty and twenty-five pages in length, covered a wide range of issues concerning the social order, and touched on the stock market, the gold standard,

6. Jean-Mathieu Soulerin, CSB, Letter of April 1856, in the Annales de la Propagation de la Foi, XXVIII: 308ff., in Charles Rhoume, CSB, A History of the Congregation of St. Basil to 1864, trans. K. Kirley and W.J. Young (Toronto: Basilian Press, 1975), 315-16.

7. Roume, A History of the Congregation of St. Basil, 316. 
social order, socialism and communism, labour, tariffs and foreign exchange, the abuse of the principle of private property, and interest. The pamphlets were issued by the Institute of Mediaeval Studies, among the first publications of what would develop as the renowned institute of research into the intellectual and social order of Europe's Middle Ages. Likewise, the Institute sponsored the publication of five radio broadcasts of Professor Gerald A. Phelan, Carr's successor as Director of the Institute. These talks dealt with issues of social reconstruction, the concern of the recent papal encyclical, Quadragesimo anno.

For his part, Fr. Joseph O'Donnell, CSB, provided the impetus for the foundation of 'The Social Ethics Club' at St. Michael's during 1935, and the members discussed a number of topics including the Necessity of Principles, Private Property, Christian Art, Just Wage, Just Price, and Communism. In 1936 a new association, 'The Study Club,' was formed and the initial speaker was journalist Henry Somerville. The 'Catholic Action Club' was founded at St. Michael's in 1936: 'The movement started in Elmsley House, where a group of interested students met for the purpose of banding together in order to more effectively carry out a select program of Catholic Action.' The first speaker to address the club was social philosopher Fr. Edwin Garvey, CSB. The members of the club were attracted to the type of work being done at Catherine de Hueck's Friendship House, and committed themselves to contributing some time each week to supporting the efforts of this settlement house work. Basilian scholastics, studying either as undergraduates at the University of Toronto, or in the theology programme at St. Basil's Seminary, formed 'The Social Justice Club,' which met regularly on Sunday evenings and had special sessions for visiting speakers.

Perhaps the most successful of these clubs, and almost certainly the one which had the greatest impact on the public, was 'St. Michael's Social Guild.' The Guild offered a number of activities, ranging from stage plays to lecture series. It functioned in close conjunction with St. Michael's Extension Department, which developed about this time and exhibited a clear concern for expressing Catholic social teaching. One of the favourite devices employed by the Guild was to introduce a piece of 'legislation' concerning some social question before a parliamentary-type forum and to debate the issue. Participants included professors and students and the public was invited to attend. Approximately one hundred people attended these Friday night forums.

The years 1936-38 represented the height of concern and interest in social questions on campus, but activity on the part of the Social Guild continued into the 1940s. Altogether, the variety of clubs and activities indicates a considerable interest in dealing with the current social distress at several levels of reflection and activity. This was matched by similar programmes in other areas of the city.

As well, a back-to-the-land experiment was initiated at St. Michael's with the dual intent of assisting suffering welfare recipients in the city with better food, housing, and prospects in the country, and also of developing a working farmschool which would provide rural people with a solid education. One of the perceptions of the period was that when youth went to the city for an education, they seldom if ever returned to their rural areas. This alienation impoverished 
rural districts by stripping them of their most capable people. The alternative to education in the city appeared to be no education at all, and neither was this desirable. Accordingly, Fr. Michael Oliver, CSB, and those who worked most closely with him in the project, Frs. Wilfrid Dore, CSB, and Joseph McGahey, CSB, believed they could make something of a transitional school, one which would convey the elements of a strong education, with respect for the training and values necessary for the continuation and improvement of rural culture. ${ }^{8}$ Fr. Oliver noted that both content and direction of elementary and high school systems emphasized preparation for professional or commercial life, and he lamented the absence of a proper preparation for rural life. ${ }^{9}$

After much planning, a property was purchased and six families were established in 1936. As many as sixty persons at a time found a place at Marylake Farm, the former property of Sir Henry Pellat, of Casa Loma fame, and by 1939 at least three families had been prepared for employment elsewhere. After four years, however, the mortgage was found to be too heavy to continue and this necessitated the sale of the property to a group of Augustinian monks fleeing persecution in Nazi Germany. The project was certainly successful in alleviating the distressed circumstances of the dozen families who participated in it, and was likewise a welcome home for the three dozen children who benefited from the security provided for family life, as well as the abundance of food and living space. Altogether, however, the project failed in its purpose of developing a long-term institution for bridging differences between rural and metropolitan areas.

The weakness lay in the fact that goodwill and effort, without sufficient structure and something more than a loosely defined co-operative base, could hardly effect permanent societal change. Fr. Dore observed that many of his confreres considered him and Frs. McGahey and Oliver 'to be darn fools,' and the larger Basilian community was not able or willing to jeopardize its financial credibility by mortgaging its future to such an uncertain venture.

While the Basilian Fathers failed to sustain the resettlement scheme, their efforts to encourage a variety of Catholic Action endeavours at St. Michael's College in the 1940s and 1950s met with considerable success. From the early 1950s St. Michael's served as a key centre for the development of the Young Christian Worker movement in English-speaking Canada. Fr. Dore worked with members of a Young Christian Student group dedicated to co-operative home building projects. Some of the YCW people already had contact with the Institute of Social Action at St. Patrick's College in Ottawa, and in July 1953 a Central Administrative Board (CAB) of Toronto Housing co-operatives was established. Beginning in July 1953, and running for several years, CAB men and women

8. Interview, Fr. Wilfrid Dore, CSB, Toronto, 13 Oct. 1979.

9. M.J. Oliver, CSB, 'Memorandum,' File: Marylake Farm, Carr Papers, Congregation of St. Basil Archives, Toronto. 
offered weekly introductory talks at St. Michael's, and with Fr. Dore's assistance, the classes became a part of the adult education programme at the College. ${ }^{10}$ Out of this first study group at St. Michael's, fourteen of the original thirty members completed the course and went on to develop their own co-op homes. Members' salaries ranged from $\$ 2,800$ to $\$ 4,200$ annually, and none could have afforded their homes other than by co-operative building.

Other endeavours in co-operative housing were also stimulated by social activism at St. Michael's College. In 1953, a student, Fr. Mathias Lu of Thorold, secured Institute of Social Action information from St. Patrick's College, and began a new co-operative neighbourhood for seventeen families. The Chinese priest was familiar with co-operative work in China and Italy, and he had previously studied at St. Francis Xavier College in Antigonish. ${ }^{12}$ The building members arranged start-up funds through co-op effort and moved into their new homes after two years of hard work. Under Father Lu's direction, two more building groups were formed in subsequent years. ${ }^{13}$

This range of Catholic Action undertakings-co-operative homebuilding, study clubs, rural settlements, and college programmes of social study - suggests that while social action initiatives were not the dominant concern of the College, they were very much present on campus and involved a good many people. Some groups of Catholic activists, such as the Young Christian Workers, had only loose ties with the College, but the contacts they formed on campus through spiritual direction or by using college facilities for their meetings were of vital importance to the workers. As at other such institutions in the province, public lectures, assemblies, and courses all indicate a claim on Church teaching and a willingness to engage social questions from a variety of scholarly disciplines.

\section{Section 5: St. Patrick's College, Ottawa}

Throughout the 1950s leadership in the area of Catholic social action initiatives in Canada continued to come from Antigonish. In Ontario, however, this Eastern influence was increasingly supplemented by courses and programmes sponsored by the Institute of Social Action (ISA) at St. Patrick's College

10. James Moorman, '168 Families in Toronto Diocese Have Built Homes the Co-op Way,' Register, 9 June 1956; 'Local Action Being Taken on Housing,' Register, 24 Oct. 1953; 'Co-op Housing for Toronto District Promoted at St. Michael's College,' Register, 10 Oct. 1957; 'Co-op Housing Lectures Re-open at St. Michael's College,' Register, 28 Feb. 1958. Also interview with Fr. E. Lawlor, Toronto, 5 Oct. 1980.

11. 'Fourteen Families Move into Co-op Homes,' Register, 31 Dec. 1955.

12. 'Homes at Half Price: Co-op Plan at Thorold,' Register, 13 June 1953.

13. 'Families Build Own Homes, Save $\$ 2,500$ to $\$ 4,0000$,' Register, 6 Aug. 1955. 
in Ottawa. The Institute was formally founded in 1951, but classes predated the foundation by at least two years. ${ }^{14}$

Fr. L.K. Poupore, OMI, Rector of St. Patrick's from 1944 to 1953, played a key role in the formation of the Institute of Social Action, and served as Director, but credit for the foundation is usually accorded to Fr. Marrocco, the first Director of the newly formed Social Action Department of the Canadian Catholic Conference of Bishops. During his time in Ottawa, Fr. Marrocco lived with the Oblates of Mary Immaculate at St. Patrick's College and taught courses there. His most significant work, however, was accomplished by encouraging the development of the ISA, and serving as a roving ambassador for its programmes in his capacity as SAD Director. The non-credit adult education programmes, and the enthusiasm of several Oblates and faculty members, combined with a continuing flow of interested students to sustain a vital and growing programme through two decades.

The college link proved invaluable for the work of the Social Action Department, for the Directors were able to call on the resources of library and faculty to serve the needs of developing programmes and approaches to social questions. In turn, the ISA depended for its continuity on a dedicated body of volunteers, men and women who were responsible for cultivating the Institute. Even Antigonish benefited from its programmes and publications dealing with domestic life, credit unions, labour unions, family life, and youth. Above all the ISA was responsible for fostering a successful programme of co-operative housing.

The annual activities of the Institute of Social Action began with a Social Action Rally at St. Patrick's College in late September. Here a distinguished speaker was engaged to spark the interest of the several hundred people who attended, and to introduce them to the classes and lecture series being offered by the Institute during the year. In 1951, Peterborough's Bishop Joseph G. Berry, 'a nationally known social worker,' advised an audience of five hundred that the courses offered by the ISA were designed to 'get the principles of religion soundly back into Canadian business, education and family life.' 15

The Institute worked from the premise that 'many Catholics are too silent or too negative in their social thinking ${ }^{16}$ and attempted to develop a lay leadership educated to accept the responsibility of translating thought into action at the local, provincial, and national levels of Canadian life. Members believed that

14. L.K. Shook, Catholic Post-Secondary Education in English-Speaking Canada (Toronto: University of Toronto Press, 1971), 252-56. St. Patrick's was formally incorporated as a college in Carleton University in 1968.

15. 'Social Action Study Course Takes Practical Turn at Ottawa School,' Register, 29 Sept. 1951, 1 .

16. Ibid. 
the object of social action is the 'Salvation and Christianizing' of social institutions. The human person is part of, and influenced by, his culture, neighbourhood, occupation, leisure time pursuits, social status, the theatre, the press, and government. It is the aim of social action to humanize and Christianize these institutions. ${ }^{17}$

The following year Msgr. Coady served as rally speaker. ${ }^{18}$ The Nova Scotian spoke of the importance of adult education. He saw commitment as a second significant ingredient in any formula for change, commenting that the real test lay in the response to the question: "Have you the courage to come out with a social program that will incur the odium of the great and powerful interests of society?'19

Coady's challenge corresponded with the purposes of the Institute and he saw in such agencies the real hope for introducing social reform into the body politic. For the next dozen years the courses, lectures, and field-work programmes of the Institute attempted to involve men and women in developing and implementing solutions to a multitude of problems. In 1955, for example, 160 students were registered in the five non-credit courses offered that year. A further thirty men and women were working on the preparation of a 'Homemaker's Course,' and ten others were doing research on 'Problems of Rural Life.'

The approach to the Homemaker's Course: A Study Guide with Discussion Questions ${ }^{20}$ was similar to that undertaken for other Institute projects, generally following the Catholic Action watchwords, 'See, Judge, and Act.' Their publication flowed from work initially undertaken as a summer project in 1951 when a group of ISA volunteers interviewed families to determine urgent needs and questions. ${ }^{21}$ Such surveys called for personnel and organization, and the first years of the decade witnessed the conjunction of more than a dozen young people, most of whom remained to form the core of the Institute through the next twelve years.

George Wicks had been with the British army and was sent to Ottawa from Geneva to serve as the Resettlement Officer for the International Refugee Organisation of the United Nations. He was in charge of Canadian immigration for a time, and in that capacity worked with Fr. Marrocco, director of Catholic

17. 'Object of Social Action, Social Action Newsletter, Vol. 1 (15 Jan. 1955), Ottawa: Institute of Social Action, St. Patrick's College, File: PC101, Archives Deschâtelets, Ottawa.

18. Rev. F.A. Marrocco to Msgr. M. Coady, 9 July 1952, St. Francis Xavier Archives, Antigonish, Nova Scotia.

19. 'Need Adult Education to Reconstruct World,' Ensign, 11 Oct. 1952, p. 3.

20. Ottawa: St. Patrick's College, Institute for Social Action, 1958, 222, Archives Deschâtelets.

21. Interview, Gerald E. Clarke, Ottawa, 31 Jan. 1980. 
Immigration Aid. Under Wicks' direction the office processed more than 100,000 applications. ${ }^{22}$ Later, he became thoroughly involved in the ISA work.

Another central figure among the ISA staff was Mary Kehoe, an Ottawa University alumna who was active in the YCW and had received her initial training in Catholic Action with that organization between 1948 and 1950, while clerking at External Affairs. Her contact with the ISA was established through one of the courses offered in 1949-50, shortly prior to beginning work in the Public Relations Department of the Canadian Congress of Labour. ${ }^{23}$ She interrupted her work with the ISA for a time in the mid-1950s, but returned again in 1961 in time to do much of the revision of the ISA Course on Labour Unions, and to launch St. Patrick's successful efforts in Credit Union Administration courses. She co-ordinated these courses during the nine years after 1962. As much as anyone, and far more than most, Mary pioneered feminine and lay initiative in church and marketplace. ${ }^{24}$

Yet another member of the ISA volunteer band was Gerald Clarke, an RCAF veteran who attended St. Patrick's College until 1949, then lectured at St. Dunstan's University. ${ }^{25}$ On his retum to Ottawa in 1951 he became involved in the work of the ISA, eventually heading the Co-operative Housing section and co-authoring the housing manual. Along with many others, these three developed a structured organization for the Institute of Social Action.

In Ontario the demographic shift to the cities increased through the depression and the war years, adding considerable strain to the housing market. The stream of immigrants in the post-war period continued the trend and added further stress to a difficult situation. In response to this general need, as well as to their own need for housing, a number of lay members of the Institute for Social Action undertook a co-operative housing programme near Ottawa. Subsequent demand led to the development of courses and manuals for similar groups elsewhere in the province. Shortly, promoting, educating, and supporting such groups became one of the central undertakings of the ISA.

Characteristically, Antigonish led the way earlier with the pioneering venture of Tompkinsville, Nova Scotia, promoted by the St. Francis Xavier Extension Department. ${ }^{26}$ At about the same time, in 1943, Fr. Louis Joseph Chamberland, pastor of St. Marguerite's parish in Trois Rivières, Quebec, developed a co-op-

22. Interview, George Wicks, Malignant Cove, N.S., 18 July 1980.

23. Interview, Mary Kehoe, Ottawa, 7 Mar. 1980; 'Mary Kehoe-Trade Union Pilgrim,' presentation to the Canadian Religious Conference-Ontario Region, Toronto, 3 Oct. 1981, 15.

24. 'Mary Kehoe-Trade Union Pilgrim,' 11.

25. Interview, Prof. Gerald E. Clarke, Ottawa, 31 Jan. 1980; Profile, Programme booklet, Ninth Catholic Social Life Conference, Halifax, Nova Scotia, Oct. 1961. Courtesy, Robert Walsh, Grimsby, Ontario.

26. For a reference to the significance of this project see 'Advantage of Cooperative Stressed in Briefs Presented to Governments,' Register, 7 Apr. 1945, 8. 
erative housing venture for his people with the assistance of Le Centre social/Social Centre, at the University of Ottawa. ${ }^{27}$

During the summer of 1951 members of the Institute of Social Action conducted a study of family life in the Ottawa area. Among other concerns the study touched on the question of housing. In September the researchers concluded that inadequate housing facilities constituted a major problem for families and speculated that a co-operative approach to home-building could provide a solution to the problem. The conclusion of this group was confirmed by the census returns of 1951 which indicated a Canadian housing shortage of approximately 750,000 units. $^{28}$

As a result of these findings, the ISA launched a major co-op housing research project in May 1952. ${ }^{29}$ Some sixty volunteers participated in the programme throughout the summer under the chairmanship of George Wicks. The group studied Canadian, American, Swedish, and other approaches to co-operative building. ${ }^{30}$ At the end of the summer, eight of the researchers decided to form a co-operative home building study group. By December sufficient interest had been aroused to initiate three study groups in the Ottawa area. Another group had begun in Lindsay, Ontario, in October. The rapid expansion of programmes and projects supported by the ISA led to the development of a formal co-ordinating structure, the Institute of Social Action Advisory Committee (ISAAC), in May, 1952. The early enthusiasm shown for the housing co-operative work led to the development of an Ottawa regional Central Administrative Board (CAB) in December. ${ }^{31}$

27. 'Co-operative Parish Venture Provides Low-Cost Homes in Three Rivers Area,' Register, 17 Jan. 1948, 3. Connections between the Antigonish Movement and Quebec Co-operatives are easily established. See Mobilizing for Enlightenment, Antigonish, Extension Department, St. FX, 11.

28. 'Co-operative Building Urged to Combat Shortage of Housing,' Ensign, 22 Aug. 1953 , 2. A more informal national survey by the Ensign during the autumn of 1952 revealed that one million Canadian families wished to purchase or build new homes in a year when an estimated 75,000 construction starts were recorded. 'Co-ops Answer Housing Needs,' Ensign, 23 Feb. 1953, 3.

29. G. Clarke, 'Co-operative Homebuilding in Ontario, 1953-1957' (M.A. thesis, University of Ottawa, 1959), 1; Mary Kehoe, 'Chronological Summary,' 2.

30. Interview, George Wicks, Malignant Cove, Nova Scotia, 18 July 1980.

31. Clarke, 'Co-operative Home Building,' 3. The ISA group was not the first in the area to follow the co-operative building route. Across the river, in Wrightville, Quebec, a small group of families had begun a co-operative housing venture in the autumn of 1948 . With study club plans from the Ligue Ouvrière Catholique, and financial support from Hull's Notre Dame Caisse Populaire and the Union St. Joseph, this group had completed fifteen homes and was working on ten others in December 1952. 'Half Price Houses, But Not by Magic,' Ensign, 6 Dec. 1952, 3. 
During the next months the ISA group published a series of booklets detailing the step-by-step approach to successful home building. They investigated federal legislation requirements and established a working arrangement with the federal Central Mortgage and Housing Corporation (CMHC) permitting the application of the co-operators' physical labour on the project to the total value of the home and allowing that labour as the down-payment required by CMHC rules, thus establishing the creative concept of 'sweat-equity.' In the seven-year period through the end of 1959 , forty Ontario groups followed the ISA programme, providing housing for 3,200 persons in the 750 single-family units at a cost of $\$ 8,500,000$. In subsequent years a great many other projects followed this example. The study materials proved to be a key part of the housing scheme. ${ }^{32}$

In the autumn of 1952 the co-operators appealed to the Ontario government for legislation favouring such housing, akin to similar legislation in the eastern provinces. The following February the Institute published a Guide to Co-operative Housing, its eight booklets totalling 190 pages detailing the results of the summer research and laying down the principles for developing a homebuilding study group. Meetings with the CMHC during the spring of 1953 led to the federal agency's decision to finance the construction of the first thirty-four houses, enabling commencement of construction in June $1953 .^{33}$

The publication of the Guide attracted considerable media attention, and the Ensign launched a six-part series on co-operative housing in the spring of 1953. At the annual meeting of the Canadian Trades and Labour Congress in Ottawa, Fr. Marrocco's speech on co-operative housing won enthusiastic applause. ${ }^{34}$

32. 'Heritage Series Tells Co-op Story,' Register, 30 Jan. 1960, 1. During the years 1946 to 1953 at least five groups had built co-operative housing projects in Ontario. Between 1953 and 1957 it is known that ten other such projects were completed in Ontario. While these groups did not use ISA study materials, a minimum of five of them resulted as off-shoots of the ISA work: Clarke, 'Co-operative Home Building,' 15. In 1952, 155 co-operative housing associations across the country were providing housing for hundreds of families in Nova Scotia, Quebec, and Ontario, as well as in two prairie centres. 'Canadians find Homes, Co-operative Housing Units,' Ensign, 3 May 1952, 2.

33. Clarke, 'Co-operative Homebuilding,' 3-4. This section of the paper is greatly indebted to Prof. Clarke's thesis on the Institute's co-operative housing work. His study offers full statistical information for 21 of the first 27 home building societies, through 1957. The initial support of the CMHC was reinforced the following year with the replacement of the National Housing Act of 1944 by new legislation permitting the agency to accept the manual labour of the members as a part of the total cost of the houses. This 'sweat equity' then served as the major portion of the required down-payment. The application of this principle enabled cash-short workers to secure a home, the only possibility the vast majority had for ever acquiring a home.

34. 'Co-operative Building Urged to Combat Shortage of Housing,' Ensign, 22 Aug. 1953. Premier Leslie Frost, also appearing at the convention, and impressed by the 
Later, at the September gathering of the Canadian Congress of Labour in Montreal, the Social Action Director made a similar appeal, urging the 800 delegates to develop a method for easier access to 'starter funds' for home building societies. $^{35}$

From the outset of the Marrocco Home-Building Society the ISA adopted the key Antigonish principle of emphasis on instruction and preparation, expressed in the motto: 'Education before Excavation.' Study groups lasted at least a year before the building group could be launched, a daunting demand for any who had imagined that the co-operative venture was an easy short-cut to cheap homes. From the beginning too, the ISA members recognized that if the programme was to work at all, the emphasis on family had to be maintained, and the mutual support of husband and wife encouraged. Accordingly, while manual labour was restricted to husbands, wives participated in meetings and offered their critical perspective on home designs. ${ }^{36}$

The Marrocco group, as most others, involved a majority of Catholics, but not exclusively so. As with most building groups, leadership was usually provided by a priest, often in personal contact with Fr. Marrocco. While these priests had little or no expertise with building, their presence and encouragement added credibility and stability to the group and they served as foils for drawing out and developing the resources of the families.

In the case of the first 512 houses, the typical builder was twenty-nine years of age and had two children when he began building. As for finances, 'The typical member eamed an income of $\$ 3,700$, made a down payment of $\$ 860$, moved into a house costing $\$ 10,630$ and undertook to repay a mortgage debt of $\$ 9,750.37$ In any comparative test co-operative homes were found to be either average or above average in size and appearance. The ISA co-operators earned salaries only two-thirds as high as the average income of all National Housing Association (NHA) borrowers, indicating that rather more Canadians were potential home owners than was currently thought possible. ${ }^{38}$ In terms of work-time the average co-operator invested 1,470 hours of manual labour on-site. The average estimated saving of $\$ 2,110$ thus suggests an hourly wage of $\$ 1.44$. This, of course,

rapid development of the co-operative society in his home town of Lindsay, promised provincial government support to aid the development of the new programme. This same TLC convention endorsed the formation of an educational department and the appointment of an educational director. In the more propitious decades of the second half of the twentieth century it is difficult to recall how few and far between adult education and extension programmes were in the country.

35. 'Urges Support for Co-op Housing,' Register, 26 Sept. 1953.

36. Gerald Clarke's study indicates that the average worker laboured 1,470 hours over a fourteen-month period (Clarke, 'Co-operative Homebuilding,' 47). Many additional hours were spent in meetings and ancillary tasks.

37. Clarke, 'Co-operative Homebuilding,' 24.

38. Ibid., 37. 
does not account for the dozens of hours spent in study and committee work. However, when it is considered that the saving was not subject to income tax, and that it was applicable, through the principle of 'sweat-equity,' to the downpayment, the significance of the saving appreciates considerably.

As the 1960s drew on, interest and participation flagged considerably. There is no indication of groups starting after 1962 or 1963, although it is likely that groups continued to use the ISA material. The development of public housing, the emphasis on co-operative ownership, and the effects of the age of affluence militated against this approach to house ownership. As base wage rates rose the inclination to embark on such a demanding project diminished appreciably.

On the positive side of the ledger, the ISA programme illustrated the potential strengths of the ordinary citizen joined with others to fulfil a common need. The ISA staff were volunteers and few people associated with the homebuilding programme derived any salary from it. The experience stands as an excellent example of clergy and church drawing people together in communal support and service for mutual benefit. ${ }^{39}$ As is evident from much of the testimony the projects were ultimately as much involved with building people as with building homes. Twenty-five years later a reunion drew some twenty-four people with nostalgic memories of the enterprise. ${ }^{40}$ Wicks testified that in our own group every single man who built advanced in salary range and to more responsible work within a short time. The experience did something to them. ${ }^{41}$ Along the way the enterprise served as an initiation into ecumenism for clerics and laity.

The accomplishments of the Institute of Social Action serve as the best example of integrated thought and action in Ontario during these three decades. The conjunction of ISA interests with those of the Social Action Department and the involvement of Fr. Marrocco and his successor, Fr. Smyth, provided lively stimulation and leadership. The presence of a dedicated body of men and women with a continuing commitment to social action concerns permitted the development of a variety of programmes and publications carefully designed to assist specific needs. At the same time, the College was limited by financial constraints and the ISA remained peripheral to the central work of teaching credit courses and fulfilling the traditional college mandate. Further funding, particularly in the form of some permanent staffing, would have assisted the work considerably.

39. In all of the building groups studied by Clarke, and in all groups which surfaced through subsequent research, a priest served as the catalyst for the local groups. Most often there was some connection with Antigonish and/or Bishop Marrocco, as well as evidence of some other social action endeavour on behalf of his people.

40. Interview, G. Clarke, Carleton University, 31 Jan. 1980.

41. Interview, G. Wicks, 18 July 1980. 


\section{Section 6: Reflections}

In an article on a phenomenon which emerged in Nova Scotia in the 1920s, Jim Lotz has written that 'the Antigonish Movement is universally recognised as a significant contribution to the theory and practice of social change. ${ }^{42}$ The Movement has had a profound and continuing impact on the rest of Canada, particularly on the Roman Catholic Church. Wherever one looks to see Catholic social action initiatives, especially in English-speaking Canada through the 1960 s, there is almost always an Antigonish connection of one sort or another. It is true that other areas and undertakings do not show the same consistent devotion to and development of co-operative ideals. But then even in the Antigonish hinterland the prospects for such undertakings have waxed and waned over a seventy-year period. What is clear in the case of Antigonish, and what these researches establish likewise for Ontario, in a diminished but significant manner, is the continuing interest in and commitment to a religious life and expression which is dynamic and innovative rather than static and enclosed. This is not to say that the church has abandoned its responsibility for monitoring and mediating the religious tradition, but it is to say that the church has had a clear conception of the important connection between the expressive order of faith teaching and values and the behaviour order of action and application of those values within the social, economic, and political matrix of Ontario society.

From the days of Basilian educational establishment in pre-Confederation Ontario, the generating concept was that the lot of the poor Irish immigrants could be changed for the better. It was believed that the commitment to improvement, in this case through the development of educational institutions supportive of this people's cultural and religious heritage, would provide access to the cultural, economic, and social rewards of the broader society. In a similar manner, under the pressures of the depression, initially, and of the demographic shift from country to city spurred by the Second World War and the labour and technological changes accompanying and following on the war, Catholics, both lay and clerical, looked for new models and new institutional responses. These were intended to assist workers to achieve social and economic security sufficient for their selfperception as capable, dignified human beings. Clearly Max Weber would read the direction and influence of Ontario Catholicism through these decades as sustaining his abiding interest in religion as promoting social change rather than emphasizing the conservation of the established, and frequently out-moded, conventions.

As regards the relationship between 'expressive' on the one hand and 'behaviour' on the other, these materials indicate a clear and conscious relationship between the traditional educational activities of schools, classrooms, and

42. Jim Lotz, 'The Historical and Social Setting of the Antigonish Movement,' Nova Scotia Historical Quarterly 5, 2 (June 1975): 99-116. 
curricula, and the dynamic of social and economic adaptations in the world outside of the school. Robert Bellah finds that behaviour in twentieth-century American life frequently emphasizes the individual at the expense of social and communal arrangements and needs. ${ }^{43}$ Such behaviours are deeply rooted in the expressive activities of the sustaining institutions of the society, among which the educational are paramount. It is clear that the activities described in these materials were contrary to the negative 'expressive individualism' to which Bellah alludes and which is essentially self-seeking and self-serving. Rather, the complex of attitudes and actions supported and sustained through these efforts attempted to foster attitudes and an atmosphere of co-operation, collaboration, and community building.

In his studies of religion Max Weber spoke of the evolution of religious experience as moving from the order of magic, where the magician represented his/her own powers and abilities; to priesthood, where the priest, as it were, 'gathered up' the soul or essence of the community, stood for the community, and represented the community, rather than himself/herself; and finally, the prophet, who frequently mediates between the first two and is presented as 'the agent of rationalisation.' These categories are not unrelated to Weber's analysis of the typical expression of authority according to the categories of traditional, legal, and charismatic. Here the traditional is seen to represent the rules and customs established through communal experience and custom; the legal represents the critically considered universe of a logical, rational, modernizing society; and the third, the charismatic, the category of authority resident in a person or small group, and often precipitating movement between the first and second categories. Where magic seeks control over the affairs of gods and creation, religion represents surrender to the gods and the order of the universe. In Gregory Baum's reading, 'People trust the priest because they believe in the divine power residing in the community; people trust the magician because of his special,

43. See R.N. Bellah, W.M. Sullivan, A. Swidler, and S.M. Tipton, Habits of the Heart: Individualism and Commitment in American Life (New York: Harper \& Row, 1985); R. Bellah, R. Madsen, W.M. Sullivan, A. Swidler, S.M. Tipton, The Good Society (New York: Random House, 1992). Bellah, and the sociologists who constitute the core of 'the Good Society Project,' are not alone in their concern for the balance between individual freedoms and the surrounding, sustaining community. Writers such as Richard Sennett and Christopher Lasch have mapped out some of this territory earlier in works such as The Fall of Public Man (New York: Random House, 1978), and The Culture of Narcissism (New York: Warner Books/Little Brown, 1983). For a brief review of the difficulties encountered in attempting to address political questions through the vehicle of education see Chapter Three of Lawrence A. Cremin, Popular Education and its Discontents (New York: Harper \& Row, 1989). 
inexplicable power. ${ }^{44}$ With respect to the relationship between priest and prophet,

the priest acts as a member of a priestly caste, exercises a power that resides in the community and hence speaks largely as the protector of the existing social order, while the prophet speaks at a distance from the religious institution and traditional society. ${ }^{45}$

According to this reading much of the activity witnessed in the preceding studies falls between the categories of priestly and prophetic, and the cleric is often on the cusp of exercising authority in a charismatic venture. In the case of the farm experiment, and of many credit union and co-operative developments, clergy took the lead in stimulating their people to address local economic and social questions and to take some control of their economic environment. Here clergy were stepping out of their purely priestly role and assuming a prophetic stance, albeit within the microcosmic order of parish, school, or diocese. Nevertheless, it was by virtue of their priestly roles that they attained sufficient legitimacy in the eyes of their people to assume the prophetic character. At this point they were able to challenge their people to recognize the talents and abilities among them and to begin utilizing hitherto hidden resources for the benefit of individuals and the group. Again and again, at St. Michael's College, St. Patrick's and other colleges, and in countless parish settings, we see clerics with little or no 'practical' talents summon up the latent resources of people who were frequently economically marginalized. These then proceeded to organize what must be considered highly complex entrepreneurial activities and to carry them successfully to conclusion through an extended series of intricate manoeuvrings. While it would be a mistake to over-play the role of clerics here, it is clear that they provided an enabling function which was crucial and otherwise lacking. Likewise, however, it is clear that the latent resources, skills, and labours of several thousand laity ultimately brought these projects and institutions to birth and maturity.

Finally, what do these reflections suggest regarding Weber's dim view of human prospects down the road of an increasingly rational culture and society? As the depression responses showed in dozens of different ways, and as demographic, labour, habitation, and technological shifts accompanying and following the Second World War suggest, under the pressure of necessity, persons and institutions are both more adaptable and innovative than Weber's conclusion warrants. Certainly the experience of modernity, with its stultifying bureaucracy, corporate rigidity, predilection for violent confrontation, and institutional resis-

44. Gregory Baum, Religion and Alienation: A Theological Reading of Sociology (New York: Paulist Press, 1975), 88.

45. Ibid., 90. 
tance to adaptation, is all too well documented. Fortunately, the capacity for democratic institutions to find new ways, and to 'muddle through' to new expressions and freedoms, is also well demonstrated in the present generation.

Globalization has provided greater knowledge of and sensitivity to the needs and concerns of other cultures and belief systems than has ever existed. While demographics are daunting, and many millions still starve, societies have adapted to the task of feeding more than double the human population of a half-century ago. Technological advances and communication and transportation services are available to provide solutions which require only the human wisdom and political will to implement. The difficulty here lies not with the limits of reason and the rationalized systems of implementation, production, and delivery but rather with the restrictions of tribal, ethnic, religious, national, and racial accretions which blind to possibilities and tend to restrict to the limits of the old and frequently failed.

The dynamics of adaptation revealed in these micro-studies instruct us as to the possibilities for meeting the complex of questions posed at the macro level by the contemporary world. During the last generation the world has witnessed in the events and dictates of the Cold War, the arms race, and the global confrontation of ideologies, the reality of the 'iron cage' incarnate. The events of the last decade illustrate, at the macro level, the possibilities for a transformed consciousness and the possibility of expanded freedoms hardly dreamed of in the preceding decade. These micro-studies suggest several of the key components for avoiding the limitations of a rational culture, and the threatening piffalls of the 'iron cage.' The solutions are not so novel, but conviction, conversion, and commitment are always fresh and only personally enfleshed.

Ontario's impoverished Irish immigrants of 150 years ago needed and responded to educational initiatives within the context of a belief system directed towards the care of others and the nurturing of community and society. Knowledge alone, without some propelling and compassionate value system, can, as has been seen in the ideological drives of this century, generate destructive rages and cages. These studies suggest some possibilities, rather, for sages: where the religious foundational belief structures are directed toward innovative service; where preparation in the expressive order of education expects action for community and society rather than for a self-serving expressive individualism; and where power and authority are exercised from and on behalf of the community in service of its communal needs. The solution to the spectre of the iron cage lies within the dynamic of informed and compassionate persons and societies. Such persons and societies are formed only gradually as they are socialized and informed by the current, valued, and dominant attitudes and events of their locale. For the few thousands of persons dealt with in these studies and so informed through a generation of studies and experiences with co-operatives, credit unions, labour unions, and ancillary activities, life and change came to be seen and known as welcome and integrating rather than alien and fragmenting experiences. For 
these people, at least, a solid basis for appreciating and contributing to benign social change was well established. ${ }^{46}$

46. Some of the materials in sections 3 and 4 have previously been published in B. Hogan, 'Ivory Tower and Grass Roots: The Intellectual Life and Social Action of the Congregation of St. Basil, Archdiocese of Toronto, 1930-1960,' in Catholics at the 'Gathering Place' : Historical Essays on the Archdiocese of Toronto, 1841-1991 ed. M. McGowan and B. Clarke (Toronto: Canadian Catholic Historical Association, 1993), 255-74; and B. Hogan, 'The Institute of Social Action and Social Catholicism in Canada in the 1950s,' Historical Studies 54 (1987): 125-44. 